\title{
5-Alpha-Reductase Deficiency
}

National Cancer Institute

\section{Source}

National Cancer Institute. 5-Alpha-Reductase Deficiency. NCI Thesaurus. Code C120193.

Deficiency of 5-alpha-reductase type 2 in genital tissues resulting in reduced local concentration of dihydrotestosterone (DHT). 